\title{
Effect of textile woven fabric parameters on its thermal properties
}

\section{REZUMAT - ABSTRACT}

\section{Efectul parametrilor țesăturilor asupra proprietăților termice ale acestora}

Acest studio urmărește să investigheze relația dintre proprietățile de construcție a țesăturii și proprietățile termice. În acest scop, au fost utilizate trei structuri de legătură de bază, trei compoziții fibroase, cinci mase de suprafață și patru grosimi. S-au determinat rezistența termică la convecție $R_{C V}$, rezistența la conductivitate termică $R_{C D}$, puterea adiatermică și conductivitatea termică a țesăturilor. În cadrul acestui studiu, legătura pânză a prezentat cele mai mari proprietăți termice, în timp ce legăturile diagonal și atlaz au prezentat cele mai scăzute caracteristici termice. Tipul de fibră afectează foarte mult proprietățile termice într-un mod foarte diferit. Creșterea masei și a grosimii suprafeței a fost direct legată de puterea adiatermică, rezistența termică și conductivitatea termică.

Cuvinte-cheie: proprietățile țesăturii, rezistența termică, puterea adiatermică, conductivitatea termică

\section{Effect of textile wovenfabricparameters on its thermal propert}

This paper aims to investigate the relationship between fabric construction properties and its thermal properties. For this aim three basic weave structures, three fiber compositions, five surface mass and four thicknesses were used. The thermal convection resistance $R_{C V}$, thermal conduction resistance $R_{C D}$, adiathermic power and thermal conductivity of all fabric samples were determined. In this research the plain weave structure showed the highest thermal properties while the twill and satin weave depicted the lowest thermal characteristics. The fiber type affects deeply different thermal properties. The increase of the surface mass and thickness was directly bound to the adiathermic power, thermal resistance and the thermal conductivity.

Keywords: fabric properties, thermal resistance, adiathermic power, thermal conductivity

\section{INTRODUCTION}

Different Standards had defined the thermal comfort as being "that condition of mind which expresses satisfaction with the thermal environment" (ISO 2005; ASHRAE 1974). To reach the thermal comfort two conditions must be fulfilled; a sensation of thermal neutrality between the skin and the body's core temperature and the body's energy balance (Häusler and Berger, 2002). Therefore, the comfort can be defined as 'a pleasant state of psychological and physical harmony between a human being and the environment' (Das and Ishtiaque, 2004). In addition, the physiological comfort and the garment role may be summarized in the figure 1. In this fact, the Physiological comfort is deeply dependent on the used garment properties. The clothing parameters are the used materials nature and its structure such as porosity, the air permeability, the thermal conductivity, the effective resistance and the thermal efficiency [6, 7]. Many several studies investigated the effect of the garment structure on the physical and thermal properties. This paper studied the effect of the weave structure, the fiber composition, the surface mass and the thickness of the woven fabric on its thermal property. The comfort of the woven structure depends on the external climatic and the weave structure (Saville, 1999). The effect of the weave structure affects deeply the porosity of woven textile fabric which leads to the variation of the thermal property (Matusiak and Sikorski, 2011). Therefore, it is found that plain fabrics have the highest value of thermal resistance (Frydrych et al., 2002). Every linear structure has its special characteristic; therefore, these properties influence the porosity which results in decreased thermal conductivity (Varshney et al.,

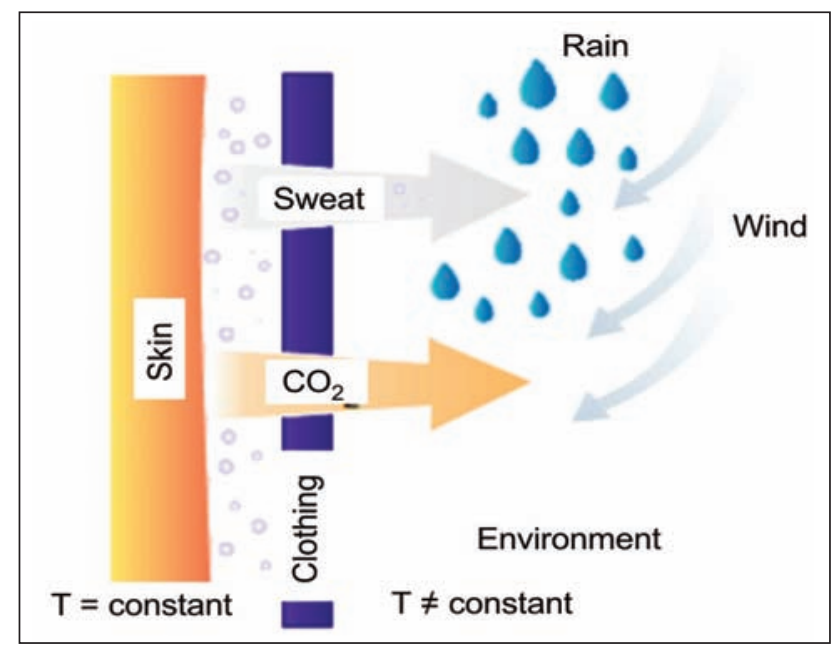

Fig. 1. The body's thermoregulatory mechanism (Grażyna et al., 2016) 
2010). The effect of the fiber type on the thermal resistance properties fabrics was studied by Afzal (Afzal et al., 2014). Then, the effect of fibre morphology, yarn and fabric structure on thermal comfort properties of fabric was investigated (Pac et al., 2001). Therefore, Khoddami et al. (2009) showed that the thermal resistance of woven fabric increases while increasing the sample thickness. Thus, many researches (Havenith, 2002; Milenkovic et al., 1999) demonstrated that heat resistance increases by increasing the fabric thickness.

The relationship between thermal properties and the textile woven structures has been studied by several researchers (Matusiak, 2006; Süle, 2012). It was reported that the entrapped air layer within fabrics was of great importance in determining heat flux. Finally, the fabric properties determine the thermal resistance and thermal conductivity. Par definition, the thermal conductivity expresses the ease of conduction of heat through a porous medium. The heat is transmitted mainly by conduction, in the solid phase of the fibrous materials, and by conduction, convection, and radiation in its fluid phase. The flux of heat transfer is:

$$
\varnothing_{\mathrm{T}}=\varnothing_{\text {cond }}+\varnothing_{\text {conv }}+\varnothing_{\text {rad }}
$$

where: $\varnothing_{\text {cond }}$ is the conductive flux, $\varnothing_{\text {conv }}-$ the convective flux, $\varnothing_{\text {rad }}$ - the radiative flux.

It is experimentally demonstrated the existence of relationship between the heat flux $\varnothing$ and the temperature gradient through a solid medium.

$$
\varnothing=-\lambda \operatorname{grad} T
$$

In this field, many models were examined and mathematical models given (Militky and Kremenakova, 2010; Wang et al., 2008; Eucken, 1940; Maxwell, 1954; Levy, 1981) respectively by equation (3), (4), (5) and (6) which were put in as shown in table 1 , where:

$P$ is the volume fraction of material 1 ;

$K_{e}$ - effective thermal conductivity;

$K_{p}$ and $K_{s}$ - thermal conductivity with parallel and series arrangement;

$K_{i}$ and $v_{i}$ - the thermal conductivity and volume fraction of i material;

$v_{1}$ and $v_{2}-$ the volume fraction of materials 1 and 2;

$K_{1}$ and $K_{2}-$ the thermal conductivity of materials 1 and 2 .

\section{MATERIALS AND METHODS}

In this study, three basic textile fiber was used: the cotton, the blend cotton-polyester and the polyester. Then, three weaving concepts are utilized to evaluate the effect of investigated factors on the physical and thermal properties.
EFFECTIVE THERMAL CONDUCTIVITY EQUATION

$$
K_{e}=\frac{\left(K_{p}+K_{s}\right)}{2}
$$$$
K_{p}=P K_{1}+(1-P) K_{2}
$$$$
K_{s}=\frac{K_{1} K_{2}}{P K_{2}+(1-P) K_{1}}
$$$$
K_{e}=K_{s} / 2\left(\sqrt{1+8 K_{p} / K_{s}}-1\right)
$$$$
K_{p}=\sum_{i=1}^{N} K_{i} v_{i}, K_{s}=1 / \sum_{i=1}^{N} \frac{v_{i}}{K_{i}}
$$$$
K_{e}=K_{1} \frac{2 K_{1}+K_{2}-2\left(K_{1}-K_{2}\right) v_{2}}{2 K_{1}+K_{2}+\left(K_{1}-K_{2}\right) v_{2}}
$$$$
K_{e}=K_{1} \frac{2 K_{1}+K_{2}-2\left(K_{1}-K_{2}\right) F}{2 K_{1}+K_{2}+\left(K_{1}-K_{2}\right) F}
$$$$
F=\frac{2 / G-1+v_{2}-\sqrt{\left(2 / G-1+v_{2}\right)^{2}-8 v_{2} / G}}{2}
$$

$$
G=\frac{\left(K_{1}-K_{2}\right)^{2}}{\left(K_{1}+K_{2}\right)^{2}+K_{1} K_{2} / 2}
$$

These weaves are the plain weave which consists of yarns interlaced in an alternating fashion one over and one under every other yarn. The second is the twill weave which is more pliable than the first and it has better drapability while maintaining more fabric stability. The last pattern is the satin weave which is a very pliable weave and is used for forming over curved surfaces. The textile structures weaves, the mass per area and the thickness used for this study with their characteristics are shown in table 2.

The fabric weight and thickness values were measured according to ASTM D3776 (2011) and to ASTM D1777-96 (2007) respectively. The measurement of the adiathermic power is carried out with a heating

\begin{tabular}{|c|c|c|c|c|c|}
\hline & & & & & Table 2 \\
\hline \multicolumn{6}{|c|}{ PROPERTIES OF THE TESTED TEXTILE FABRICS } \\
\hline Material & Weave & $\begin{array}{c}\mathrm{Nm} \\
\text { (Weft) }\end{array}$ & $\begin{array}{c}\mathrm{Nm} \\
\text { (Warp) }\end{array}$ & $\begin{array}{l}\text { Warp } \\
\text { count }\end{array}$ & $\begin{array}{l}\text { Weft } \\
\text { count }\end{array}$ \\
\hline \multirow{3}{*}{ Cotton $(100 \%)$} & Plain & 52 & 48 & 34 & 28 \\
\hline & Twill & 52 & 48 & 34 & 28 \\
\hline & Satin & 52 & 48 & 34 & 28 \\
\hline Cotton / Polyester & Plain & 48 & 50 & 34 & 28 \\
\hline Polyester (100\%) & Plain & 48 & 50 & 34 & 28 \\
\hline \multicolumn{6}{|c|}{ Surface mass $\left(g / \mathrm{m}^{2}\right)$} \\
\hline Cotton $(100 \%)$ & 140 & 155 & 170 & 180 & 200 \\
\hline \multicolumn{6}{|c|}{ Thickness (mm) } \\
\hline Cotton $(100 \%)$ & 0,46 & 0,49 & 0,52 & & \\
\hline
\end{tabular}
body covered with the sample to be tested as shown in figure 2 . The test environment must have a 


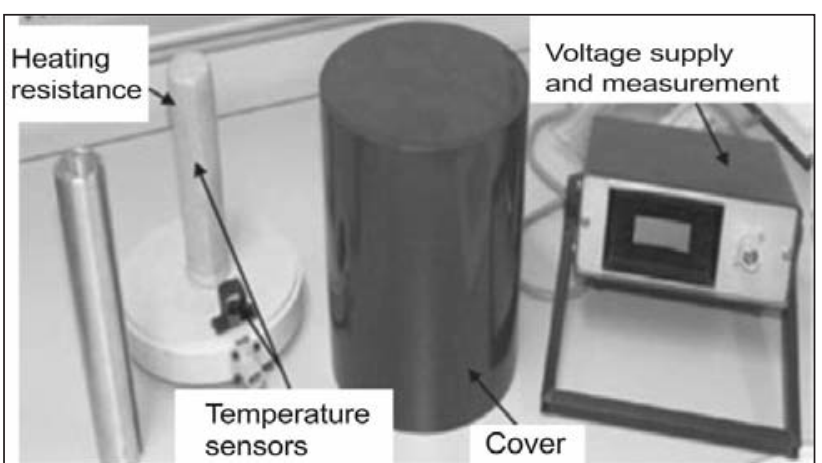

Fig. 2. Experimental device of the adiathermic property determination

perfectly controlled temperature and humidity $\left(20^{\circ} \mathrm{C}\right.$ $\pm 2{ }^{\circ} \mathrm{C}$ and Relative Humidity $65 \% \pm 2 \%$ ).

\section{RESULTS AND DISCUSSION}

\section{Effect of constructional parameters on adiathermic power}

In this section, the effect of weave structure, the fiber type, the thickness and the mass area on comfort properties are investigated. As the comfort properties are generally related to adiathermic power, the thermal resistance and thermal conductivity, these parameters are discussed. These observed parameters contributed to the thermo-physiological comfort of the fabrics.

The adiathermic power is defined as the capacity of the fabric to oppose the pass of the heat flux into its structure. In this part, this thermal property was discussed. According to the experimental results, it can be noted that different woven parameters structure had significant effect on the adiathermic power. First, each weave structure has a specific pattern of yarn interlacing points between the warp and the weft. It can be concluded from the experimental graphs that the adiathermic power value is related to the density of yarn interlacing points. The lower density gives important porosity and air permeability which means lower adiathermic power. Therefore, the plain weave has the highest adiathermic power. This can be explained that this weave has the maximum yarn interlacing points between warp and weft. On the contrary, while decreasing the yarn interlacing points between warp and weft, the adiathermic power decreases. This result is given by the twill and satin weave. The figure 3 indicated that the satin weave has the lowest value of adiathermic power, which is understandable, because this fabric is characterized by the lowest mass per square meter and relatively small thickness.

It is known from the literature that the polyester fibers indicate much lower thermal insulation than the cotton fibers. This is may explained the thermal properties (the adiathermic power, the thermal resistance and the thermal conductivity) behavior for the fabric manufactured of $100 \%$ cotton. For the fabric consisting of $100 \%$ polyester, it shows that the thermal properties are very important than each compound of

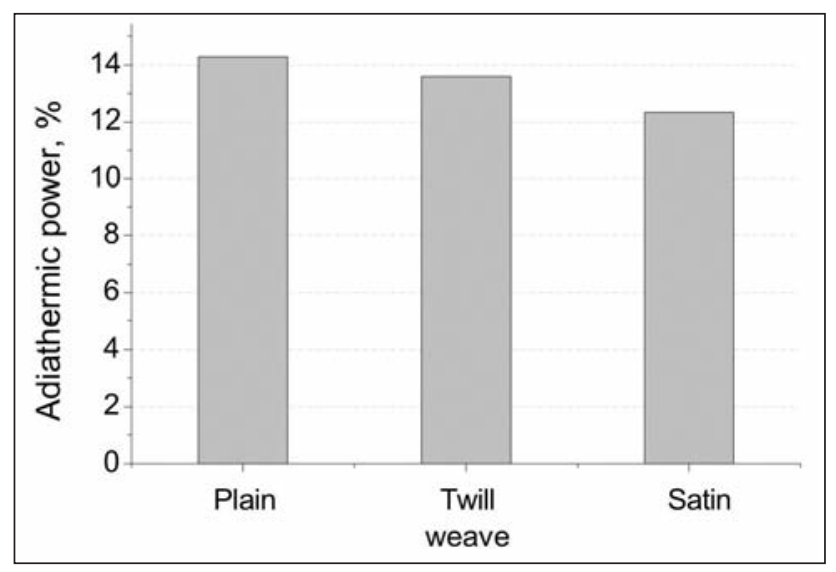

Fig. 3. Variation of the adiathermic power according to weave structure of woven fabric

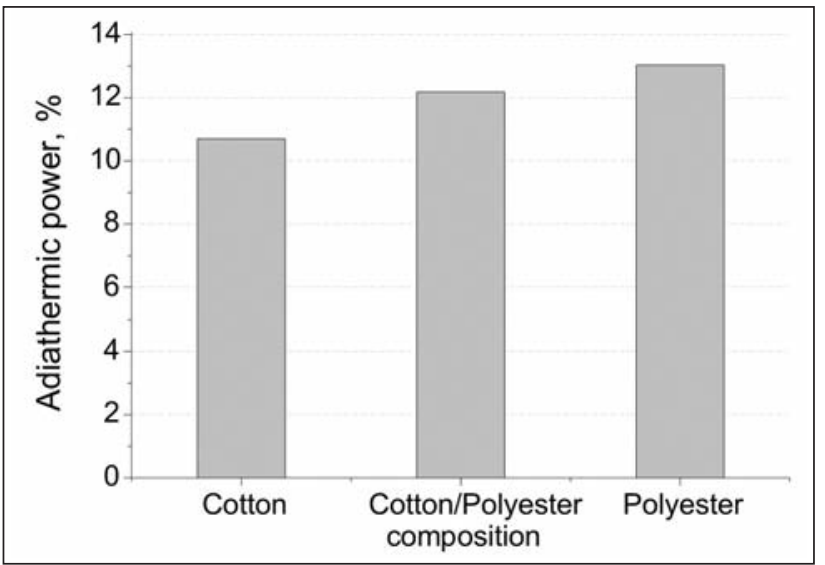

Fig. 4. Variation of the adiathermic power according to fiber composition

blend cotton/polyester which indicates the effect of insulation properties of the cotton. Therefore, the thermal behavior of the blend fabric (cotton/polyester) is in relation of the percent high content of polyester fibers in the sample as shown in figure 4 . Hence, with the higher content of cotton fibers indicates the higher thermal properties.

The adiathermic power increases due to increase in mass area and fabric thickness as well as shown in figure 5. This is explained on the fact that by increase

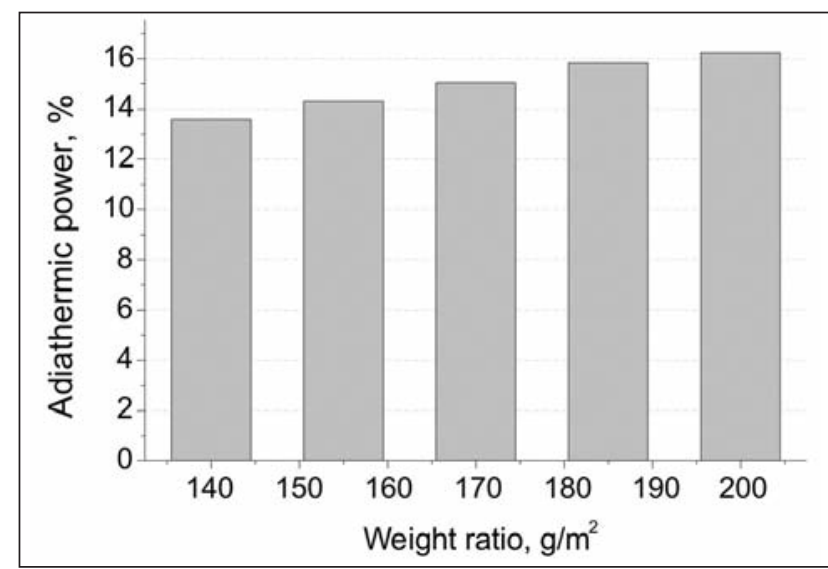

Fig. 5. Variation of the adiathermic power according to mass per area of woven fabric 


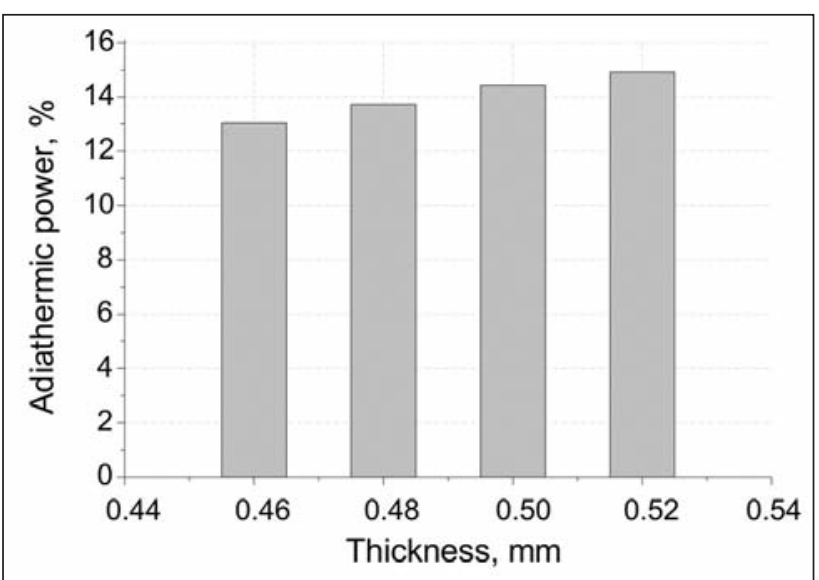

Fig. 6. Variation of the adiathermic power according to thickness of woven fabric

in fabric thickness, the fiber weight per unit area increases. This increase in fibrous material, having a higher thermal property than air, increases their contact points with each other and influences the convenient heat flow across the fabric.

The experimental results show that fabric thickness is in direct proportion with adiathermic power of the fabric as shown in figure 6 . When the fabric thickness increases, the air gaps in the fabric structure increases. As the air is a good thermal insulator, therefore by increasing fabric thickness the thermal properties and the adiathermic power increases as well. In the same consideration, as the fabric thickness increases also the weft count $(\mathrm{Nm})$ or the higher yarn diameter increase. Hence, increases in the adiathermic power of the fabric.

\section{Effect of constructional parameters on thermal resistance and conductivity}

The thermal property of woven fabrics was deeply affected by surface properties, which were determined by geometric structure. This geometry was given by the weaving technique, the yarn properties (composition, size, twist and diameter), weft count and warp density. This property was discussed as the thermal conduction resistance $\mathrm{R}_{\mathrm{CD}}$ and the thermal conductivity. The thermal resistance of a fabric refers to its ability to resist the heat flow through it. The lower the thermal resistance, the better will be the comfort for hot climatic conditions. The thermal conductivity was defined as the measure of conducted heat pass though unit thickness under $1^{\circ} \mathrm{C}$ heat difference. These two factors were discussed as function of the weave type, the fiber composition, the surface mass and the thickness of woven fabric.

First, the plain weave has many intersections which make this weave very denser and stiffer. Contrarily, the twill weave has less intersections and the satin has important floats which create a shiny surface. These weave properties provide the highest value of thermal conductivity and the lowest thermal resistance for the plain weave. While increasing the yarn float, the thermal resistance increases and thermal conductivity decreases. The variation of these properties was due to bigger pores in the fabric which helps getting more air entrapped into the fabric structure. This more quantity of air will be trapped into the structure and play important role in the variation of these thermal properties.

Second, the fiber composition had important effect on thermal resistance and conductivity. Hence, the thermal conductivity of woven polyester fabric was slightly lower than cotton and blend cotton/polyester fabric. Materials with a lower thermal conductivity have higher resistance to heat flux. This result can be explained by the yarn structure of cotton composition. In third part, the increase of the mass area of woven fabric generates the incrementing of the thermal conduction resistance and the decrease of the thermal conductivity which is explained by the entrapped air in the woven structure. Therefore, the increase of the woven surface area leads to increase of air in the structure. Hence, air has important insulation property, there are its increase in the structure leads to lower thermal conductivity and the highest thermal resistance as shown in table 3 .

Table 3

\section{EXPERIMENTAL PROCEDURE PARAMETERS}

\begin{tabular}{|c|c|c|c|c|}
\hline & & $\begin{array}{c}\mathbf{R}_{\mathrm{cV}} \\
\left(\mathrm{m}^{2} . \mathrm{K} / \mathrm{W}\right)\end{array}$ & $\begin{array}{c}\mathbf{R}_{\mathrm{CD}} \\
\left(\mathrm{m}^{2} \cdot \mathrm{K} / \mathrm{W}\right)\end{array}$ & $\begin{array}{c}\text { TC } \\
(\mathrm{W} / \mathrm{K} \cdot \mathrm{m})\end{array}$ \\
\hline \multirow{3}{*}{ Woven structure } & Plain & 5.74 & 0.6 & 0.029 \\
\hline & Twill & 5.74 & 0.8 & 0.027 \\
\hline & Satin & 5.74 & 0.96 & 0.024 \\
\hline \multirow{3}{*}{ Fiber nature } & Cotton & 5.74 & 0.6 & 0.032 \\
\hline & Co/PES & 5.74 & 0.86 & 0.029 \\
\hline & PES & 5.74 & 0.93 & 0.026 \\
\hline \multirow{5}{*}{$\begin{array}{l}\text { Surface mass } \\
\qquad\left(\mathrm{g} / \mathrm{m}^{2}\right)\end{array}$} & 110 & 571 & ?חת & 0105 \\
\hline & 155 & 5.74 & 084 & 0.189 \\
\hline & 170 & 5.74 & 0.91 & 0.183 \\
\hline & 185 & 5.74 & 0.97 & 0.18 \\
\hline & 200 & 5.74 & 1.08 & 0.178 \\
\hline \multirow{4}{*}{ Thickness(mm) } & 0,46 & 5.74 & 0.86 & 0.034 \\
\hline & 0,48 & 5.74 & 0.883 & 0.031 \\
\hline & 0,5 & 5.74 & 0.92 & 0.029 \\
\hline & 0,52 & 5.74 & 0.957 & 0.026 \\
\hline \multicolumn{5}{|c|}{$\begin{array}{l}\text { Legend: } \\
\text { Thermal convection resistance: } \mathrm{R}_{\mathrm{CV}} \\
\text { Thermal conduction resistance: } \mathrm{R}_{\mathrm{CD}} \\
\text { Thermal conductivity: TC } \\
\text { Cotton/ Polyester: Co/ PES }\end{array}$} \\
\hline
\end{tabular}
2019, vol. 70, 1ni: I 
Finally, these same results of thermal properties obtained in the case of the variation of the surface mass are valid and confirmed in the case of the variation of the woven thickness and explained by the entrapped air in the textile structure.

\section{CONCLUSIONS}

To obtain an acceptable satisfaction and physiological comfort it is obligatory to analyze the impact of various fabric parameters on their thermal properties. This research showed that the fabric manufactured with the plain weave and each having the important mass per square and the thickness presents the best thermal properties. These properties decrease for samples presenting the highest porosity and important polyester fiber composition which are known to have low thermal insulation. However, the analysis of physical parameters of fabrics shows that the woven textile fabric having the plain weave, the highest mass per area and the thickness had the important adiathermic power and the lowest thermal resistance and thermal conductivity.

Thus, theses thermal properties are deeply related to the air permeability and fabric porosity. This is due to the increase or decrease in the structure in contact point and yarn density. In second part, the variation in air gap results in improved thermal properties.

\section{BIBLIOGRAPHY}

[1] International Organization for Standardization (ISO), (2005) Ergonomics of the thermal environment - analytical determination and interpretation of thermal comfort using calculation of the PMV and PPD indices and local thermal comfort criteria (Standard No. ISO 7730: 2005). Geneva, Switzerland: ISO.

[2] American Society of Heating, Refrigerating and Air-Conditioning Engineers (ASHRAE) (1974), Thermal environmental conditions for human occupancy (Standard No. ASHRAE 55-74). Atlanta, GA, USA: ASHRAE.

[3] Häusler, T., Berger, B. (2002) Determination of thermal comfort and amount of daylight. In: Besler GJ, editor. Proceedings of the 10th International Conference on Air Conditioning, Air Protection \& District Heating.Wrocław, Poland: PZITS; pp. 227-32.

[4] Das, A., Ishtiaque, S. Comfort characteristics of fabrics containing twist-less and hollow fibrous assemblies in weft. JTATM 3: 1-7, 2004.

[5] Grażyna, B., Iwona, F., Agnieszka, G. (2016) Fabric selection for the reference clothing destined for ergonomics test of protective clothing: physiological comfort point of view, In: AUTEX Research Journal 16(4), pp. 256-261.

[6] Fourt, L., Holies, N. (1970) Clothing: comfort and function. Marcel Dekker (New York).

[7] Song, G., Improving comfort in clothing, In: Woodhead Publishing (Cambridge), 2011.

[8] Saville, B.P., In physical testing of textiles, In: England, Woodhead Publishing Ltd., 1999, pp. 209-243.

[9] Matusiak, M., Sikorski, K. (2011) Influence of the structure of woven fabrics on their thermal insulation properties. In: FibresTexEast Eur 19(5), pp. 46-53, 2011.

[9a] Frydrych, I., Dziworska, G., Bilska, J. (2002) Comparative analysis of the thermal insulation properties of fabrics made of natural and man-made cellulose fibers. In: FibresTex East Eur 39(4), pp. 40-44.

[10] Varshney, R., Kothari, V., Dhamija, S. (2010) A study on thermo physiological comfort properties of fabrics in relation to constituent fibre fineness and cross-sectional shapes. In: J Textl 101(6), pp. 495-505.

[11] Afzal A, Hussain T, Mohsin M, et al (2014),Statistical models for predicting the thermal resistance of polyester/cotton blended interlock knitted fabrics. In: Int J ThermSci85: 40-46

[12] Afzal, A., Hussain, T., Mohsin, M., et al (2014) Statistical model for predicting the air permeability of polyester/ cotton-blended interlock knitted fabrics. In: J Text I 105(2), pp. 214-222.

[13] Pac, M.J., Bueno, M.A., Renner, M. (2001) Warm-cool feeling relative to tribological properties of fabrics. In: Text Res J 71(9), pp. 806-812.

[14] Khoddami, A., Carr, C.M., Gong, R.H. (2009) Effect of hollow polyester fibres on mechanical properties of knitted wool/ polyester fabrics. In: Fiber Polym 10(4), pp. 452-460.

[15] Havenith, G. (2002) Interaction of clothing and thermoregulation. In: Exogenous Dermatology, 1(5), pp. $221-230$.

[16] Milenkovic, L., Skundric, P., Sokolovic, R., Nikolic, T. (1999) Comfort properties of defence protective clothing. In: The Scientific Journal Facta Universitatis, 1(4), pp. 101-106.

[17] Matusiak, M. (2006) Investigation of the thermal insulation properties of multilayer textiles. In: FibresTex East Eur. 14, pp. 98-102.

[18] Süle, G. (2012) Investigation of bending and drape properties of woven fabrics and the effects of fabric constructional parameters and warp tension on these properties. In: Text Res J 82, pp. 810-819. 
[19] Militky, J., Kremenakova, D. (2010) In Prediction of fabrics thermal conductivity, In: 5th International textile, clothing \& design conference - Magic World of Textiles, Dubrovnik, Croatia, Dubrovnik, Croatia, pp. 1-6.

[20] Wang, J., Carson, J.K., North, M.F. (2008) A new structural model of effective thermal conductivity for heterogeneous materials with co-continuous phases. In: Int J Heat Mass Transfer 51 (9-10), pp. 2389-2397.

[21] Eucken, A. (1940) Allgemeine Gesetzmabigkeiten fur das Warmeleitvermogenverschiedener Stoffarten und Aggregatzustande. In: Forschung Gabiete Ingenieur,11, pp. 6-20.

[22] Maxwell, J.C. (1954) A treatise on electricity and magnetism, (3rd ed), New York, Dover Publications Inc.

[23] Levy, F.L. (1981) A modified Maxwell-Eucken equation for calculating the thermal conductivity of two-component solutions or mixtures. In: IntJ Refrig 4 (4), pp. 223-225.

[24] ASTM D3776, (2011) Standard Test Methods for Mass per Unit Area (Weight) of Fabric.

[25] ASTM D1777-96, (2007) Test Method for Thickness of Textile Materials.

\section{Authors:}

\section{SABRI HALAOUA ${ }^{1}$, ZOUHAIER ROMDHANI ${ }^{1}$, ABDELMAJID JEMNI $^{2}$}

${ }^{1}$ Unit of Textile Research Material and Process (MPTex), University of Monastir, ENIM, Tunisia

${ }^{2}$ Laboratory of study of the Thermal and Energy Systems (LESTE), University of Monastir, ENIM, Tunisia

Corresponding author:

ZOUHAIER ROMDHANI

e-mail: romdhanizouhaier@gmail.com

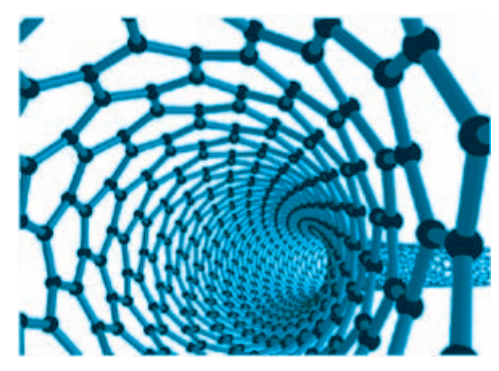

